UDC 811.162.1'42

https://doi.org/10.18485/ms_zmss.2020.97.13

\author{
Radosław Maziarz \\ Uniwersytet Przyrodniczo-Humanistyczny w Siedlcach \\ radoslaw.maziarz@uph.edu.pl \\ Radosław Maziarz \\ Siedlce University of Natural Sciences and Humanities \\ radoslaw.maziarz@uph.edu.pl
}

\title{
METAFORYKA DEFAWORYZACJI W DYSKURSIE WYKLUCZENIA. ANALIZA INTERNETOWYCH WYPOWIEDZI PRZECIWNIKÓW LGBT
}

\section{THE METAPHOR OF DEFAVORIZATION IN THE DISCOURSE OF EXCLUSION. THE ANALYSIS OF INTERNET STATEMENTS OF LGBT OPPONENTS}

\begin{abstract}
Niniejszy artykuł podejmuje temat współczesnego polskiego dyskursu publicznego, skoncentrowanego wokół środowiska LGBT. Przedmiotem badania są wybrane internetowe wypowiedzi przeciwników tej grupy społecznej. Analiza bazuje na założeniach metafory pojęciowej, a jej celem jest określenie metafor defaworyzacji, czyli takich, które wyrażają negatywną ocenę, deprecjację, segregację, dyskryminację danej grupy i prowadzą do jej społecznego wykluczenia. Analiza wykazała, że dominują trzy główne metafory defaworyzacji, których domenami są terror, choroba oraz kataklizm. Pojęcia te są obciążone szeregiem negatywnych konotacji, co sprawia, że środowisko LGBT konceptualizowane jest w negatywny sposób.
\end{abstract}

Słowa kluczowe: metafora, dyskurs, defaworyzacja, wykluczenie, LGBT.

This paper explores the contemporary Polish public discourse related to the LGBT community. The study concentrates on selected Internet statements of opponents of this social group. The analysis is based on the assumptions of a conceptual metaphor, and its aim is to determine the metaphors of defavorization, i.e., those that express negative assessment, depreciation, segregation, and discrediting of a given group and lead to their social exclusion. The analysis has shown that three main metaphors of defavorization dominate, whose source domains are terror, illness and cataclysm. These concepts are burdened with a number of negative connotations, which makes the LGBT community conceptualized in a negative way.

Key words: metaphor, discourse, defavorization, exclusion, LGBT. 


\section{Wprowadzenie}

Współczesny dyskurs publiczny coraz mocniej zdominowany jest przez wypełnione emocjami wypowiedzi, które stygmatyzują różne grupy odniesienia, utrwalają stereotypy, łamią tematy tabu i polaryzują opinię publiczną. Sprzyja temu pluralistyczny charakter społeczeństwa i dwuwymiarowość świata, który opiera się na relacji my i oni. Politycy, dziennikarze, wpływowi ludzie mediów, kręgi opiniotwórcze tworzą z przestrzeni publicznej arenę wojenną, na której najniebezpieczniejszą bronią jest język — dosadny, wulgarny, agresywny, coraz bardziej bezkompromisowy. W opinii Naruszewicz -Duchlińskiej (2015: 56) w wojnie tej porzuca się walory moralne na rzecz siły rażenia. Dopuszcza się według badaczki wszelkie środki, dzięki którym możliwa jest realizacja celu: deprecjacja obranego obiektu odniesienia. Dyskusja oparta na języku defaworyzacji ma zatem na celu nie tylko szerzenie i obronę własnych poglądów, lecz także dyskredytację przekonań oponenta. Jak stwierdza Maj (2009: 64, 69) język defaworyzacji służy werbalnemu unicestwieniu wybranego wroga za pomocą agresji i alienacji. Problematyka dyskursu wykluczenia skupia się - w oparciu o Witosza (2010: 11-18) - wokół dyskryminacji pewnych grup społecznych w celu ich wykluczenia poprzez pozbawienie możliwości współkreowania społeczeństwa, do którego przynależą. Cechą dyskursu wykluczenia jest silna polaryzacja nacechowana aksjologicznie i emocjonalnie. Cechy te są doskonale widoczne na tle tematów o zróżnicowanym rezonansie społecznym. Przykładem może być wzbudzające aktualnie ogromne emocje środowisko LGBT. Dyskurs ten prowadzony jest za pomocą bardzo bogatego, zmetaforyzowanego języka, którego domenami źródłowymi są - co wykaże analiza — przede wszystkim terror(yzm), choroby oraz kataklizmy, czyli pojęcia obciążone jednoznacznie negatywnymi konotacjami. Metaforyka defaworyzacji bazuje na retoryce anty-LGBT i stanowi formę dyskryminacji, segregacji, prowadzi do nienawiści i ostracyzmu.

Schwarz-Friesel (2014: 7-12) zauważa, że dzięki mediom powstają modele mentalne, czyli reprezentacje przedmiotu lub zjawiska w ludzkiej świadomości. Są one przekazywane odbiorcom za pośrednictwem tekstów. Dzięki modelom mentalnym poszczególne zagadnienia (np. istotne zjawiska społeczne lub polityczne) pojmowane są w określony sposób. Wypowiedzi mogą wpływać na zbiorowy sposób myślenia a nawet modelować kulturową świadomość społeczeństwa. Język może kształtować — na poziomie kognitywnym i emocjonalnym - poglądy, postawy, decyzje i wybory. Jest on narzędziem zarządzania myślami i emocjami, ponieważ umożliwia tworzenie subiektywnego obrazu świata. Massmedia kształtują opinię publiczną, ponieważ interpretują to, o czym informują, koncentrują się mocniej na wybranych aspektach i równocześnie dokonują ich oceny, poprzez perspektywę oraz staranny dobór informacji tworzą konceptualizacje, ustalają standardy, wskazują odbiorcy punkty odniesienia. Modele mentalne mogą wybiórczo odbijać poszczególne wycinki rzeczywistości, mogą również — poprzez reklasyfikację, 
dodanie lub zniekształcenie informacji — przedstawiać własne realia, które nie zawsze kompatybilne są z rzeczywistością. Modele mentalne to, jak kontynuuje badaczka, systemy przekonań ukształtowane społecznie, zakotwiczone kognitywne, które reprezentują uznane przez społeczeństwo jako uniwersalne założenia o organizacji świata. W zależności od obranej perspektywy, za pośrednictwem relacji medialnej oraz odpowiedniego komentarza pośredniczą w interpretacji i ocenie danych zjawisk. Język, dzięki zdolności kreowania modeli mentalnych, a także z uwagi na jego potencjał perswazji jest instrumentem władzy, ponieważ interpretacja rzeczywistości może przyczynić się do zmiany lub stabilizacji procesów społecznych. Van Dijk (2001: 352-358) stwierdza, że analiza dyskursu ma na celu określenie sposobu, w jaki język rekonstruuje funkcjonowanie społeczeństwa, praktyki nadużycia władzy, przypadki dominacji i nierówności i relacje między grupami społecznymi. Sprawdzonym narzędziem jest rzeczona już metafora, której funkcja opiera się na strategii werbalnej manipulacji, mającej na celu wyrażenie opinii w sposób implicytny, nie ponosząc ryzyka jej zakwestionowania. Strategia ideologiczna związana jest ze strukturami konceptualnymi, które w sposób zawoalowany przekazują różne wartości. Metafora, jak utrzymuje Partington (2006: 271294), używana jest w celu oceny wydarzeń, osób i ich zachowań, a także do kwestionowania i destabilizacji powszechnych spostrzeżeń i opinii, zaś w polityce staje się narzędziem perswazji i komunikacji wspólnych wartości.

\section{Uwagi metodologiczne}

Celem niniejszej pracy jest analiza dyskursu skupionego wokół zagadnienia LGBT pod kątem kompleksu metafor pojęciowych (w popularnym ujęciu zaproponowanym przez Lakoffa i Johnsona 1980, Kövecsesa 2002 i innych) z uwzględnieniem strategii wykluczenia i sposobu wyrażenia defaworyzacji danej grupy społecznej w przestrzeni publicznej. Perswazyjny potencjał metafory wykorzystywany jest w celu wpływania na opinię danej grupy odbiorców owego dyskursu oraz kształtowania zbiorowej świadomości społecznej. Dokonano analizy wypowiedzi, których owy potencjał oddziaływania na odbiorcę jest - w naszej subiektywnej opinii — najwyższy z uwagi na dobór metafor o największym (z perspektywy przeciwników LGBT) walorze defaworyzacji. Wyekscerpowane wypowiedzi pochodzą ze źródeł internetowych — artykułów, które ukazały się w 2019 roku w popularnych serwisach polskojęzycznych. Spośród zebranego materiału językowego wyodrębniono trzy główne domeny stanowiące najbogatsze źródło metaforyki defaworyzacji: TERROR(YZM), CHOROBA oraz KATAKLIZM. Pojęcia te wywołują naturalny sprzeciw, a w połączeniu $\mathrm{z}$ ich projekcją na model zachowania danej grupy (LGBT) automatycznie prowadzi do obniżenia lub nawet całkowitej dyskwalifikacji jej statusu społecznego. W pracy podejmujemy próbę odpowiedzi na pytanie, jak konceptualizowana jest owa defaworyzacja (na drodze jakich metafor) oraz na czym oparta jest strategia wykluczenia. 


\section{Analiza}

\section{METAFORYKA TERRORU/TERRORYZMU}

Terror(yzm) to jeden z głównych czynników zagrożenia bezpieczeństwa współczesnego człowieka, którego szczególne nasilenie obserwujemy od początku XXI wieku w związku z zamachami przeprowadzonymi w Stanach Zjednoczonych oraz Europie. Terror(yzm) zdominował ogólnoświatową przestrzeń publiczną i stał się realnym zagrożeniem kojarzonym z islamskim radykalizmem. Podobny mechanizm zależności (radykalizm $\rightarrow$ zagrożenie $\rightarrow$ strach $\rightarrow$ sprzeciw), w o wiele mniejszej skali, funkcjonuje w dyskursie poświęconym środowiskom homoseksualnym. Przeciwnicy LGBT wprowadzają do dyskursu stanowcze środki - metaforykę terroru - demonstrując zdecydowaną i bezkompromisową reakcję sprzeciwu wobec praktyk LGBT. Metaforyka terroryzmu uskutecznia poczucie zastraszenia i paraliżuje świadomość społeczną. Stygmatyzacja środowisk LGBT za pomocą kategorii terroryzmu nadaje im cechy właściwe organizacjom przestępczym, działającym w sposób świadomy, metodyczny, zaplanowany i zorganizowany, ukierunkowany na osiągnięcie własnych, niegodziwych celów. Retoryka terroru wprowadza do dyskursu elementy wojny ideologicznej pomiędzy osobami homoseksualnymi a ich przeciwnikami. W naturalny sposób narzuca ona opozycję agresor $\leftrightarrow$ ofiara, co z kolei prowadzi do opartego na ludzkim doświadczeniu wartościowania źli (agresywni, mocni, bezwzględni) $\leftrightarrow$ dobrzy (pokojowi, stabi, empatyczni). Taka narracja pełni określoną funkcję: nie tylko posiada dużą wartość retoryczną, lecz także pozwala uczestnikowi dyskursu ideologicznie zadeklarować się po którejś ze stron konfliktu i „zmaterializować”, a następnie „zlikwidować” wroga. Zazwyczaj człowiek naturalnie i świadomie wybiera kategorię dobra a odrzuca zło, przez co, analogicznie, opowiada się po stronie ofiar konfliktu. Na przykład:

[1] „Nasz Dziennik” straszy ,homoterroryzmem” $i$,genderlobby”. ${ }^{1}$

[2] (...) chciałbym, żeby nie terroryzowaly one dzieci, nie niszczyty ich niewinności (...) ${ }^{2}$

[3] Jeśli ktoś przed akcja ze stynna już nalepka widziat ich aktywność $w$ kontekście walki o tolerancję, to już nie może mieć złudzeń. Ich tolerancja to po prostu terror. ${ }^{3}$

[4] „,...) występ w Dublinie — mimo buńczucznych zapowiedzi sześciokolorowych terrorystów — odbędzie się i będzie MEGA! ${ }^{4}$

1 www.wprost.pl/kraj/428259/nasz-dziennik-straszy-homoterroryzmem-i-genderlobbyksiadz-zdziczaly-happening.html (dostęp: 1.09.2019)

2 www.tvp.info/43841010/sejm-zajmie-sie-obywatelskim-projektem-dotyczacym-seksualzacji-dzieci (dostęp: 1.09.2019)

3 www.gazetapolska.pl/20052-homobarbarzyncy (dostęp: 1.09.2019) 1.09.2019)

4 natemat.pl/283805,protesty-lgbt-w-dublinie-przed-wystepami-cejrowskiego (dostęp: 
Najbardziej radykalną metodą walki terrorystów są bezwzględne ataki z użyciem drastycznych środków, przeprowadzane z myślą o wyrządzeniu dotkliwych strat. Celem ataków środowisk LGBT jest w opinii kręgów konserwatywnych rozbicie paradygmatu małżeństwa i osłabienie tradycyjnego, chrześcijańskiego modelu rodziny, opartego na związku kobiety i mężczyzny. W większości kręgów kulturowych rodzina stanowi najwyższe dobro, jej destabilizacja budzi sprzeciw i naturalny odruch buntu oraz odrzucenia:

[5] „Ostatnio obserwuje się w Polsce ogromne zagrożenie dla demokracji i wolności człowieka poprzez dziatanie środowisk liberalno-lewicowych promujacych ideologię LGBT i gender. Środowiska te prowadza $w$ sposób radykalny atak na rodzinę $i$ wszelkie wartości chrześcijańskie (... $)^{5}$

[6] Na przyktad podpisanie tzw. karty LGBT+ (...) przedstawili niemal jako zamach na tradycyjna rodzine. ${ }^{6}$

Zatem, zgodnie z retoryką konserwatystów, społeczność homoseksualna stosuje nieakceptowane w społeczeństwie metody działania dominujące w kręgach kryminalnych, grupach przestępczych, które oparte są na przemocy psychicznej bądź fizycznej. Aktywowana zostaje relacja terrorysta — ofiara, której komponenty cechuje odmienny system pojęciowy: SPRZECIW, POTĘPIENIE, KARA, a na przeciwnym biegunie WSPÓŁCZUCIE, SOLIDARNOŚĆ, WSPARCIE itp. Perspektywa obrana przez przeciwników LGBT wyraźnie zatem polaryzuje społeczeństwo w kwestiach światopoglądowych. Na przykład:

[7] Szantaż spod znaku tęczy. Homoseksualiści w Poznaniu żądają coraz więcej.7

[8] (...) ,,tolerancja" staje się obecnie ,,zaktadnikiem środowisk LGBT (...)".8

Radykalizm, ekstremizm i fundamentalizm to kategorie łączone ze zjawiskiem terroryzmu, towarzyszą one bowiem działaniom środowisk sprzyjających jego rozwojowi, uznających przemoc jak środek i metodę realizacji swoich celów. Na zasadzie analogii do praktyk organizacji terrorystycznych traktowana jest aktywność środowiska LGBT, co utrwala ich negatywny status. Metaforyka terroru demaskuje coraz bardziej zdecydowane i bezwzględne postawy osób LGBT, które manifestują się także poprzez akty przemocy, np.:

[9] Za postulatami środowisk LGBT stoi radykalny projekt ideologiczny (...).9

5 krakow.wyborcza.pl/krakow/7,44425,25125426,sprawa-radnych-pis-ze-starego-saczai-ich-rezolucji-przeciw.html (dostęp: 1.09.2019)

6 warszawa.wyborcza.pl/warszawa/7,54420,25112253, trzaskowski-z-wysokimi-ocenami-warszawiakow-barometr-warszawski.html (dostęp: 1.09.2019)

7 niezalezna.pl/234503-szantaz-spod-znaku-teczy-homoseksualisci-w-poznaniu-zadajacoraz-wiecej (dostęp: 1.09.2019)

8 www.polsatnews.pl/wiadomosc/2019-06-19/sejmik-woj-swietokrzyskiego-przeciw -probom-wprowadzenia-ideologii-lgbt/ (dostęp: 1.09.2019)

9 www.rp.pl/Plus-Minus/308229930-Ideologia-LGBT-Zanim-upadnie-przyniesiecierpienia.html (dostęp: 1.09.2019) 
[10] „,Jeśli lewaccy ekstremiści myśla, że moga nas zastraszyć...”10

[11] Fundamentalizm środowisk LGBT przybiera na sile. ${ }^{11}$

Praktykowanie metod terroru, stosowanie agresji oraz szerzenie nienawiści jest domeną systemu totalitarnego, jaki zarzucany jest środowiskom przychylnym LGBT. Na przykład:

[12] ,,Atak na abp. Jędraszewskiego to przyktad totalitaryzmu ideologii LGBT"12

Jednym z najbardziej nieludzkich narzędzi terroru jest gwałt ${ }^{13}$, postrzegany w kulturze europejskiej jako czyn zasługujący na szczególne potępienie, łączy się bowiem z poniżeniem, odebraniem godności, brutalną ingerencją w najbardziej intymne sfery ludzkiego życia. Oceniając założenia deklaracji LGBT+ powołano się na kategorię przemocy na tle seksualnym, dokonanej na rodzicach. W podobnej retoryce oceniony został zorganizowany marsz równości. Taki kierunek prowadzenia dyskusji może mieć konsekwencje w postaci odebrania stronie przeciwnej jakiejkolwiek linii argumentacyjnej. Gwałt jest bowiem zjawiskiem społecznie nieakceptowanym, nieusprawiedliwionym, wywołującym skrajne emocje. Granie na emocjach jest mechanizmem wywierania określonych reakcji u ludzi (np. współczucia, lęku, niechęci, odrazy itp.) i kształtowania ich poglądu lub wpływania na ich opinię. Człowiek automatycznie neguje gwałt jako czyn niezgodny z wyznawanymi wartościami, a osoby, które się go dopuszczają, wyklucza poza społeczeństwo. Na przykład:

[13] Przywódcy kościołów protestanckich o tej deklaracji napisali: To krzywdzenie dzieci i gwalt na rodzicach (...) $)^{14}$

[14] Jest gwalt, jest fun" - ciagnie naukowiec i odmalowuje ogrom zniszczenia zasianego przez społeczność LGBT: „Już dawno zgwalcili Warszawe, Poznań, Wrocław i Gdańsk. Niedawno brutalnie zdeflorowali Biatystok $(. . .)^{15}$

Obrana ofensywna strategia wywoływania poczucia lęku pomaga skutecznie kształtować i kontrolować emocje uczestników dyskursu. Argumentacja opierająca się na metaforze terroryzmu jest skuteczna i trudna do odparcia, gdyż naturalną reakcją człowieka na zagrożenie jest próba jego zapobiegania. Aktywuje to pewien system obronny. Dbając o własne bezpieczeństwo stanowczo odrzucamy wszelkie przejawy terroryzmu jako coś złego,

10 telewizjarepublika.pl/protest-dwojki-lgbt-pod-redakcja-gp-jesli-lewaccy-ekstremiscimysla-ze-moga-nas-zastraszyc,82911.html (dostęp: 1.09.2019)

11 wprawo.pl/2019/07/26/nasila-sie-terror-lgbt-kioskarz-oblany-nieznanym-roztworem/ (dostęp: 1.09 .2019$)$

12 www.radiowarszawa.com.pl/ks-zielinski-ideologia-lgbt-ma-cechy-totalitarne/ (dostęp: 1.09.2019)

13 Szerzej o funkcjonowaniu metafory gwałtu na przykładzie ataku terrorystycznego na Pentagon w 2001 roku w książce G.Lakoffa (2011).

14 Debata Jedynki. Kontrowersje wokół deklaracji LGBT+, 13.03.2019.

15 www.wysokieobcasy.pl/wysokie-obcasy/7,96856,25133785,znany-profesor-o-osobach-lgbt-jest-gwalt-jest-fun.html?disableRedirects=true (dostęp: 1.09.2019) 
szkodliwego, zagrażającego życiu (zazwyczaj osób bezbronnych i niewinnych), jednocześnie opowiadając się przeciwko tym, którzy stanowią jego źródło. Postawa dezaprobaty wobec działań osób homoseksualnych wynika zatem nie tyle $\mathrm{z}$ racjonalnych przesłanek i osobistych przekonań, co przyczyn emocjonalnych, z nieświadomości dyktowanej strachem.

\section{METAFORYKA CHOROBY}

Metaforyka choroby opiera się na prostym założeniu, że zdrowy organizm to norma, zaś choroba to pewna dysfunkcja, odchylenie od normy zagrażające stabilności organizmu. Osoby heteroseksualne postrzegają się w kategorii osób zdrowych, prawidłowo funkcjonujących i z tak obranej perspektywy, na zasadzie przeciwstawienia, określają środowiska homoseksualne jako nienormalne. Dokonuje się wyraźna kategoryzacja: my, heteroseksualni — zdrowi, normalni, z kolei oni, homoseksualni - chorzy i nienormalni. Metafora choroby dokonuje podziału, którego osią jest orientacja seksualna. Na przykład:

[15] Dla nas to całe LGBT jest czymś nienormalnym. Mniejszość usituje narzucić swoje przekonania zdrowej większości. ${ }^{16}$

Zdaniem Sontag (2016: 74) metaforyka choroby odnosi się do negatywnie postrzeganych zjawisk społecznych, przy czym jej celem nie jest osąd, lecz wskazanie na represyjny charakter społeczeństwa. W kategoriach choroby postrzegane jest społeczne funkcjonowanie osób LGBT na tle heteroseksualnej większości, będącej wyznacznikiem standardu. Należy zauważyć, że w dyskursie sięga się po pojęcia związane z chorobami niebezpiecznymi, o szerokim zasięgu i najczęściej katastrofalnych następstwach. Zakres pojęciowy choroby pozwala przemodelować charakter homoseksualizmu w kierunku wstydliwej, szkodliwej anomalii. W historii ludzkości choroby były zjawiskami, które od zawsze wzbudzały strach, stanowiły zagrożenie, powodowały społeczną psychozę. Powstaje wyraźny schemat, składający się z dwóch, polaryzujących elementów: heteroseksualne, bazujące na wartościach chrześcijańskich społeczeństwo to zdrowy, właściwie funkcjonujący organizm, który jest atakowany przez chorobę, czyli środowisko osób homoseksualnych, odrzucających przyjęte przez chrześcijaństwo normy. Na przykład:

[16] Szefowa KSOZ NSZZ „Solidarnośc”" podkreślita, że przyszła także prosić o modlitewne wsparcie w walce ze szkodliwa ideologia (....). ${ }^{17}$

Choroby wywoływane są, zgodnie z wiedzą medyczną, przez bakterie i wirusy. Wirus może rozprzestrzeniać się i mutować, staje się coraz groźniejszy, a w skrajnych przypadkach śmiercionośny. Taka charakterystyka prze-

\footnotetext{
16 wiadomosci.onet.pl/kraj/daily-telegraph-homoseksualizm-w-polsce-wymaga-odwagi/ ezszgb4 (dostęp: 1.09.2019)

17 www.tvp.info/43883373/modlitwa-i-wyrazy-poparcia-dla-arcybiskupa-reakcja-nazmasowany-atak-srodowisk-lewicowych (dostęp: 1.09.2019)
} 
niesiona na działalność środowisk LGBT profiluje je jako niebezpieczne, wzbudzające nieufność i potrzebę izolacji, zagrażające zdrowiu lub życiu. Przykłady metafor choroby:

[17] Wirus LGBT. ${ }^{18}$

[18] Ogłoszenia strasza białostoczan ,bakteria LGBT”. 19

[19] To jest tylko i wytacznie ochrona matoletnich przed infekcja zboczonymi ideami oraz przed wzorcem zachowań opartym wytacznie na zaspokajaniu instynktów (..... ${ }^{20}$

Ze zmetaforyzowaną chorobą mamy również do czynienia w przypadku hasła widniejącego na naklejce „Strefa wolna od LGBT", dodawanej do jednej z polskich gazet. Wyraz strefa określa, w rozumieniu przestrzennym, pewien wydzielony obszar, przeznaczony do jakiegoś celu. Sformułowanie strefa wolna od LGBT rozumiane jest zatem jako forma światopoglądowej izolacji od kręgów homoseksualnych, jest wyrazem ich społecznego odrzucenia jako niepasującej, szkodliwej części oraz wykluczenia ze społeczności. Strefa stanowi symboliczny podział na „naszych” i „obcych”, czyli dokonuje pewnej segregacji i dyskryminacji, których kryterium stanowi orientacja seksualna.

Kręgi kościelne wyrażają mocne zaniepokojenie narastającą aktywnością środowiska LGBT w Polsce. By zaakcentować skalę zjawiska i zwiększone tempo jego rozpowszechniania się w przestrzeni publicznej, jeden $\mathrm{z}$ duchownych - w odpowiedzi na krytykę słów metropolity krakowskiego — posługuje się pojęciami określającymi masowe występowanie chorób zakaźnych:

[20] ,....) odważne stowa pasterza, które (...) wygłosit o pladze ideologii LGBTI, która naprawdę rozprzestrzenia sie jak morowa epidemia" - napisat abp Orosch. ${ }^{21}$

Sontag (2016: 63) zwraca uwagę na fakt, że choroby epidemiczne rozumieć należy jako przenośnię zamętu społecznego. Związane są one z wrogością do religii, moralności i porządku publicznego. Metaforyka chorób zakaźnych jest bardzo produktywna w kontekście dyskursu LGBT: arcybiskup Henryk Hoser używa pokrewnego terminu o charakterze hiperonimu, który dodatkowo intensyfikuje nasilenie problemu:

[21] (...) chodzi o chorobę antropologiczna zaraźliwa już o cechach pandemii. Jej ofiarami padaja rzesze ludzi uczestniczacych $w$ marszach czarnych i kolorowych. ${ }^{22}$

18 naszdziennik.pl/polska-kraj/209511,wirus-lgbt.html (dostęp: 1.09.2019)

19 bialystok.naszemiasto.pl/ogloszenia-strasza-bialostoczan-bakteria-lgbt-w-centrum/ ar/c1-7263457 (dostęp: 1.09.2019)

20 www.tysol.pl/b35074-Prawy-Sierpowy-Mikroblog-Dzieci-na-celowniku-LGBT (dostęp: 1.09.2019)

21 niezalezna.p1/283597-episkopat-slowacji-w-obronie-abpa-jedraszewskiego-jestesmywrazliwi-na-wszelkie-proby-uciszania (dostęp: 1.09.2019)

22 niezalezna.pl/283619-abp-hoser-pisze-list-do-abpa-jedraszewskiego-alegoria-o-teczowej-zarazie-jest-bardzo-adekwatna (dostęp: 1.09.2019) 
Pojęcie zaraza, podobnie jak wirus, posiada ujemny status w świadomości współczesnego człowieka z uwagi na negatywne skutki zdrowotne i społeczne, jakie wywołuje. Niesie ze sobą zagrożenia w postaci systematycznej, wymykającej się spod kontroli degeneracji zdrowych jednostek. Metropolita krakowski, M.Jędraszewski kontestując ekspansję środowisk LGBT w przestrzeni publicznej zaostrza retorykę, sięgając po metaforę zarazy [22], która wartościuje osoby homoseksualne jako zdeprawowane, negujące ogólnie przyjęte wartości. Jeden z portali internetowych komentując wspomnianą wypowiedź Jędraszewskiego cytuje ją w sposób nierzetelny [23], przeinaczając nieco słowa metropolity: w miejsce zarazy pojawia się jej konkretyzacja, określenie bakteryjnej choroby zakaźnej, dżumy, która z uwagi na jej europejską pandemię w XIV wieku budzi powszechne skojarzenia z masową śmiercią. Współcześnie dżuma charakterystyczna jest przede wszystkim dla krajów słabo rozwiniętych cywilizacyjnie. Tak prowadzona narracja wprawdzie nie zmienia kierunku argumentacji, ale ją wzmacnia i zaognia spór, ponieważ kwestionuje poziom osób homoseksualnych w kontekście ich rozwoju społecznego. Debata wykracza poza kontinuum seksualne i aktywuje ramę hierarchii społecznej. Na przykład:

\section{[22] Tęczowa zaraza. ${ }^{23}$}

[23] Autor artykułu przytacza kontrowersyjna wypowiedź metropolity, w której ruch LGBT nazwat ,tęczową di்uma". ${ }^{24}$

Kumulacja określeń różnych chorób w poniższej wypowiedzi służy egzaltacji negatywnych odczuć, jakie budzi środowisko homoseksualne. Autor słów nie pozostawia wątpliwości odnośnie braku akceptacji w stosunku do kręgów LGBT, skazując ich na ostracyzm:

[24] Nalaskowski krytykuje druga stronę za milczaca akceptację tego, że „tyfus, dżuma, ospa to odmiana normalności”, i wzywa do obrony (... $)^{25}$

Warto zauważyć, że metaforyka choroby tworzy — co jest, jak wiadomo, esencjalną cechą metafory pojęciowej — koherentny system, w ramach którego wykazuje kumulatywny charakter: bakteria $\rightarrow$ wirus $\rightarrow$ zaraza $\rightarrow$ plaga $\rightarrow$ epidemia $\rightarrow$ pandemia, co pozwala na stopniowanie emocji, ostrożne dozowanie argumentów i kontrolowanie dyskursu.

Ruch LGBT opisany jest za pomocą parametrów choroby psychicznej, która zaliczana jest do chorób najbardziej wstydliwych, skrywanych, często mocno zakłócających kontakt chorego z otoczeniem, niszczących relacje społeczne. Zaburzenie psychiczne często wywołuje poczucie alienacji, czyli sy-

23 Wystąpienie metropolity krakowskiego, Marka Jędraszewskiego (2019)

24 dorzeczy.p1/110115/Liberalowie-boja-sie-zamieszek-z-powodu-antygejowskichwypowiedzi-Kosciola.html (dostęp: 1.09.2019)

25 www.wysokieobcasy.pl/wysokie-obcasy/7,96856,25133785,znany-profesor-oosobach-lgbt-jest-gwalt-jest-fun.html?disableRedirects=true (dostęp: 1.09.2019) 
tuacji, w której — za Niewiadomską i Chwaszcz (2010: 85) — osoba chora czuje się oderwana od obszarów rzeczywistości, które są dla niej ważne, a także od sfer osobistego funkcjonowania. Taka wykładnia w stosunku do środowiska LGBT sytuuje je daleko poza centrum życia społecznego, funkcjonującego według skonwencjonalizowanych reguł zachowania. Retoryka Jędraszewskiego kwestionuje zdolność środowiska homoseksualnego do współtworzenia świata opartego na konserwatywnym systemie wartości, odrzuca je jako nieintegralną i niekomplementarną część społeczeństwa.

[25] Abp Jędraszewski znów o „obtakańczych ideologiach” LGBT, gender $i$ Karcie WHO. ${ }^{26}$

Spektrum metaforyki choroby tworzy metafora rozkładu organizmu. Robert Biedroń, założyciel partii Wiosna, czołowa postać świata polityki, automatycznie budzi skojarzenia ze wspieraną przez niego społecznością LGBT. Polityczna aktywność Biedronia i posiadany przez niego kapitał zaufania społecznego podlega krytycznej ocenie w kategoriach choroby powodującej martwicę tkanki. Jej następstwem jest amputacja obumarłej kończyny bądź, w ostateczności, śmierć chorego. Biedroń przedstawiony został w roli ogniska zła rozprzestrzeniającego się we współczesnym świecie polityki - coraz bardziej zepsutym, skłóconym, podzielonym, segregującym i wykluczającym obywateli. Na przykład:

[26] Robert Biedroń powoli wyrasta na druga po Januszu Palikocie postać, symbolizująca gangrene w polskiej polityce. ${ }^{27}$

Rozkład może mieć charakter nie tylko indywidualny, lecz także kolektywny. Zgnilizna jest niejadalna, cuchnąca, odrażająca, powoduje naturalny odruch wymiotny. W przełożeniu na domenę docelową symbolizuje kompletny rozkład systemu wartości, a jako zaatakowany organizm postrzegana jest cała współczesna kultura zachodnia i jej mocno nadwyrężona kondycja moralna. Liberalny, zachodni świat jest dla konserwatystów siedliskiem demoralizacji, która niszczy współczesnego człowieka. Na przykład:

[27] Wmawia nam się Zachód jako coś wspaniałego, pięknego, do czego powinniśmy dażyć, tylko ten Zachód już w dużej mierze zgnit - mówit i podkreślit, że jeżeli naprawdę mamy bronić Zachodu, to „,musimy zupetnie odwrócić spojrzenie, a nie patrzeć na LGBT, na seksualizację dzieci w szkołach czy na parady różnego rodzaju odszczepieńców (...)". ${ }^{28}$

Za Sontag (2016: 9-65) stwierdzić możemy, że chorobę nowotworową cechuje - w porównaniu do innych chorób - wyjątkowo negatywny status.

26 www.tokfm.pl/Tokfm/7,103085,25171035,abp-jedraszewski-znow-o-oblakanczychideologiach-lgbt-gender.html (dostęp: 1.09.2019)

27 wpolityce.pl/polityka/456353-biedron-wlasna-piers-nadstawia-w-obronie-lgbt (dostęp: 1.09.2019)

28 dorzeczy.pl/kraj/97488/Prof-Roszkowski-To-jest-poczatek-konca-cywilizacji.html (dostęp: 1.09.2019) 
Rak w ludzkim ciele pełni rolę intruza, który działa w sposób okrutny, potajemny i podstępny, utożsamiany jest z nieszczęściem i cierpieniem (fizycznym i psychicznym), traktowany jest jak wyrok śmierci, jako coś porażającego zmysły. Metaforyka raka przywołuje procesy biologiczne szczególnie szokujące i odrażające, rak to - jak kontynuuje autorka - degeneracja, która zamienia żywą tkankę w twardy guz. Umiejscowienie środowisk homoseksualnych w roli nowotworu, który żeruje na (zdrowym) społeczeństwie powoduje ich zupełną negację, stanowcze odrzucenie jako coś skrajnie negatywnego, absolutnie nieakceptowanego, jako wroga, którego należy bezwzględnie zwalczyć. Każda forma protestu przeciwko LGBT to uwarunkowana cywilizacyjnie, instynktowna reakcja, forma koniecznej terapii, której celem jest zniszczenie zaatakowanych komórek i zapobieżenie ich rozprzestrzenianiu. W przypadku metaforyki nowotworowej kontrast między nami oraz naszym wrogiem jest zdecydowanie najmocniej zarysowany, ponieważ nie znajdujemy absolutnie żadnych zdroworozsądkowych argumentów za akceptacją choroby atakującej i rujnującej nasze ciało: coś, co chce nas zabić, musi zostać zlikwidowane. Mechanizm działania choroby nowotworowej: powolny, ale systematyczny i śmiertelny rozrost przerzucony został na interakcje w obrębie społeczeństwa. W roli zaatakowanego organu występuje Kościół, w strukturach którego także stwierdza się osoby o orientacji homoseksualnej. Dyskurs otwierający przestrzeń konotacyjną nowotworu wyklucza możliwość jakichkolwiek rozwiązań kompromisowych. Na przykład:

\section{[28] Lobby homoseksualne jest jak nowotwór. ${ }^{29}$}

[29] Kościót to nasza Matka Najświętsza, ale ona ma homo-raka, który ja pożera. ${ }^{30}$

Reasumując, metaforyka choroby bazuje na naturalnych potrzebach człowieka — zdrowiu i szczęściu, które gwarantują komfort emocjonalny i fizyczny. Próba pozbawienia kogokolwiek prawa do szczęścia wywołuje naturalną reakcję sprzeciwu i negacji tego, co owy porządek zakłóca. Człowiek nie godzi się na umieranie. Takie założenie dyskwalifikuje akceptację społeczności LGBT z uwagi na potencjalne źródło nieszczęścia, jakie stanowią. Retoryka choroby aktywuje także prawdopodobny, logiczny scenariusz przyczynowo -skutkowy: źródto choroby - zachorowanie - symptomy choroby - choro$b a$ - diagnoza-leczenie - wyzdrowienie, itp., co zakłada, że osoby LGBT są zdrowotnie niestabilne, mogą zarażać i wymagają leczenia. Naturalna reakcja obronna - konieczność odizolowania „chorych” od „zdrowych” — prowadzi do dyskursu wykluczenia: osoby homoseksualne stanowią niekompatybilny fragment społeczeństwa, wartościowany jako gorszy. Kałuża (2017: 232) zwraca uwagę na fakt, że odwoływanie się do chorób ciężkich prowoko-

29 www.fronda.pl/a/ks-tadeusz-isakowicz-zaleski-dla-frondy-lobby-homoseksualnejest-jak-nowotwor,126907.html (dostęp: 1.09.2019)

30 wpolityce.pl/polityka/447503-ks-prof-oko-homo-rak-pozera-kosciol (dostęp: 1.09.2019) 
wało reprezentantów danej ideologii do uzasadniania radykalnych rozwiązań i sankcjonowania rozwiązań ekstremalnych. Choroba uzasadnia defaworyzację, stygmatyzację, wykluczenie poza nawias społeczny lub eliminację tego, co w mniemaniu danego ustroju jest zagrożeniem dla istniejącego ładu społecznego.

\section{METAFORYKA KATAKLIZMU}

Katastroficzne wizje końca świata przepełnione przerażającymi, działającymi na wyobraźnię scenariuszami towarzyszyły człowiekowi od dawna. Utożsamiane są one $\mathrm{z}$ upadkiem istniejącego porządku, zniszczeniem, cierpieniem i nieszczęściem na globalną skalę. W takiej retoryce zakotwiczone są wypowiedzi kręgów konserwatywnych w kontekście dyskusji o społecznych następstwach związków par LGBT. Uznawane są one za realne zagrożenie cywilizacyjne, na które narażony jest współczesny człowiek. Metaforyka mająca swoje źródło w nieprzewidywalnym świecie natury znajduje szerokie zastosowanie w charakterystyce specyficznych dla gatunku ludzkiego postaw, z uwagi na nieprzebrane bogactwo praw rządzących naturą i możliwość ich szczegółowej projekcji (opartej na wyolbrzymieniu) na sferę życia człowieka i jego otoczenia. Cechy właściwe zjawiskom naturalnym przypisuje się ludziom obrazowo przedstawiając motywację ich zachowań wynikających z podstawowych, naturalnych instynktów.

W opinii władz Kościoła i środowisk skupionych wokół niego, postępujący liberalizm to niezwykle niebezpieczne zjawisko. Jest źródłem moralnego kryzysu współczesnego człowieka i pogwałceniem kanonu jego chrześcijańskich zasad. Rozpad dotychczasowego systemu wartości oraz jego następstwa dla ludzkości zostały wyolbrzymione do rozmiarów fatalistycznej wizji końca świata. Na przykład:

[30] Seksualizacja dzieci, podważanie tożsamości ptciowej ludzi, rozwalanie rodziny to jest początek końca cywilizacji - uważa prof. Wojciech Roszkowski. ${ }^{31}$

[31] Ideologia LGBT to w dluższej perspektywie zaglada naszej planety i próba zasiedlenia naszej matki Ziemi istotami nieszczęśliwymi (... $)^{32}$

[32] Nasi biskupi roztaczaja w wielu wypowiedziach wizję apokaliptycznego zagrożenia, które nadciaga nad Polskę, polski Kościót i wszystkie świętości. Pochodzi ono - twierdza — od środowisk LGBT+.33

31 dorzeczy.pl/kraj/97488/Prof-Roszkowski-To-jest-poczatek-konca-cywilizacji.html (dostęp: 1.09.2019)

32 poranny.pl/kolejne-protesty-przeciw-marszowi-rownosci-tym-razem-klub-wiezionych-internowanych-represjonowanych-oraz-znow-marcin-sawicki/ar/c1-14285811 (dostęp: 1.09.2019)

33 www.tygodnikpowszechny.pl/nowina-o-zarazie-159819 (dostęp: 1.09.2019) 
Metaforyka zagłady/apokalipsy przyczynia się do intensyfikacji i wyolbrzymienia zjawiska, co sprawia, że LGBT konceptualizowane jest już nie jako marginalny problem o charakterze lokalnym, lecz globalnym, dotyczącym całej ludzkości i cywilizacji w ogóle. Zwalczanie tego problemu jest konieczne, gdyż skutki mogą być tragiczne i nieodwracalne. Taka narracja legitymizuje strategię etykietowania osób LGBT jako śmiertelnie niebezpiecznych i bezwzględnego usunięcia ich z życia publicznego.

Na domenie końca świata skonstruowane są również wypowiedzi będące manifestem dążeń do odrzucenia idei LGBT w sposób radykalny i ostateczny. Efekt wykluczenia wzmocniony jest odpowiednio czasownikami oczyścić (= usunąć coś, co przeszkadza) oraz uratować (=uwolnić od czegoś, co stanowi zagrożenie):

[33] Tylko „Armagedon” jest w stanie oczyścić tę planetę. ${ }^{34}$

[34] Uratować nas może tylko kataklizm, bo taki świat zgnity bezbożnością i zmurszały nienawiścia zginać musi! 35

W obrębie metaforyki kataklizmu wyróżnić możemy również metaforę wody (powodzi), która, jak zauważymy, aktywuje schemat mechaniki działania cieczy rozlewającej się z dużą siłą i prędkością, nie zważając na żadne przeszkody będące na jej drodze. Przekładając to na realia dyskursu otrzymujemy model ofensywnej, dla wielu zbyt natarczywej polityki prowadzonej przez środowiska homoseksualne. Jednym z zarzutów stawianych przez kręgi kościelne pod ich adresem jest bowiem nachalna, pozbawiona moralnej estetyki promocja, której konsekwencją może być ekspansja zjawiska zagrażającego - w opinii Kościoła — sferze duchowej współczesnego, znajdującego się w głębokim kryzysie moralnym człowieka. Na przykład:

[35] (...) ,zło zagrażajacych nam ideologii gender i LGBT rozlało sie po Polsce, zatruwając serca i umysty Polaków i wyrządzając im ogromne duchowe szkody (... $)^{36}$

Wizję skomasowanego, zorganizowanego ataku o charakterystyce zjawiska naturalnego o zasięgu ogólnokrajowym roztacza również Arcybiskup Andrzej Dzięga [36]. Stosowana przez niego metaforyka powodzi, o bardzo silnym potencjale obrazowania, aktywuje skojarzenia z nagłym, niepohamowanym, nieobliczalnym żywiołem powodującym niewyobrażalne, masowe szkody. W podobnym tonie na temat nasilenia się działań ruchu LGBT, niosących ze sobą liberalne wartości sprzeczne z polskim konserwatyzmem (określane mianem zepsucia) wypowiada się podkarpacki radny Jacek Kotula [37]:

34 kukiz.dorzeczy.pl/swiat/104876/Chca-zyc-w-czystosci-Byli-dzialacze-LGBT-manifestowali-w-USA.html (dostęp: 1.09.2019)

35 nczas.com/2019/05/01/biskup-zawitkowski-ostro-o-zboczencach-wiosenne-lgbt-wy -nawet-grzeszyc-normalnie-nie-potraficie-pachniecie-tylko-bezwstydem/ (dostęp: 1.09.2019)

36 wiadomosci.onet.pl/kraj/jasna-gora-arcybiskup-jedraszewski-o-zagrazajacej-ideologii-gender-i-lgbt/9g1v3tb (dostęp: 1.09.2019) 
[36] "Fala ida przez Polske, organizacyjnie zsynchronizowane, jakby odgórnie zarzadzane, a prawdopodobnie i opłacane, spotkania i przemarsze". 37

[37] Dla Kotuli LGBT jest następna fala zachodniego zepsucia $i$ sekularyzacji. ${ }^{38}$

W zakresie metaforyki kataklizmu odnajdujemy również motyw biblijny:

[38] Marsz Równości w Biatymstoku. „Będzie sodoma i gomora”. 39

Metaforyka kataklizmu prowadzi do kreacji fatalistycznej wizji świata opanowanego przez pary homoseksualne, co, według orędowników tradycyjnych wartości, prowadzi do wynaturzeń i zagraża dotychczasowemu ładowi społecznemu. Budowanie dyskursu w oparciu o model apokaliptycznego kataklizmu przejaskrawia przedmiot debaty, wprowadza ją na inny, wykraczający daleko poza relację zwolennik - przeciwnik poziom dyskusji, nadając jej przebiegowi formę misji, mitycznej walki. Nasilenie potencjału zagrożenia, jakie przypisywane jest osobom LGBT, uzasadnia nasilenie dynamiki wymiany argumentów.

\section{Podsumowanie}

W ramach podsumowania stwierdzić należy, że aktualny dyskurs publiczny skupiony wokół środowiska LGBT cechuje wysoki stopień metaforyzacji wypowiedzi. Pod użytym przez nas pojęciem metaforyki defaworyzacji rozumiemy taki sposób konceptualizacji zjawisk, który skutkuje niekorzystnym osądem, deprecjacją, segregacją, werbalną dyskryminacją, potępieniem a w konsekwencji społecznym wykluczeniem grupy, której owe zjawiska dotyczą. W ramach dyskursu wykluczenia dominują trzy metafory, których domenami źródłowymi są TERROR(YZM), CHOROBA oraz KATAKLIZM. Metafory te aktywują modele mentalne, które owe wykluczenie utrwalają, ponieważ posługują się mechanizmami nieakceptowalnymi społecznie, wywołującymi bezsprzecznie instynktowną negację. Choroba utożsamiana jest z bólem, cierpieniem (fizycznym i psychicznym), odrzuceniem i samotnością, utratą godności, wyniszczeniem organizmu, agonią a czasami śmiercią. Choroba wyklucza prawidłowe funkcjonowanie i szczęśliwe życie zgodnie z naturalnymi oczekiwaniami człowieka. Odizolowanie od osoby chorej bądź też podjęcie walki z chorobą stanowi zatem naturalną reakcję człowieka. Terror(yzm) bazuje na zarządzaniu poczuciem bezpieczeństwa oraz na wywołaniu i kontroli strachu - emocji, która paraliżuje racjonalne i skuteczne my-

37 www.tvn24.pl/wiadomosci-z-kraju,3/koscielni-hierarchowie-przestrzegaja-przedlgbt-polska-i-swiat,959100.html (dostęp: 1.09.2019)

38 wiadomosci.onet.pl/kraj/daily-telegraph-homoseksualizm-w-polsce-wymaga-odwagi/ezszgb4 (dostęp: 1.09.2019)

39 bialystok.wyborcza.pl/bialystok/7,35241,24997563,marsz-rownosci-w-bialymstokubedzie-sodoma-i-gomora.html (dostęp: 1.09.2019) 
ślenie oraz działanie jednostki. Terror(yzm) pociąga za sobą ofiary wśród ludzi. Życie stanowi wartość najwyższą a groźba jego utraty wyzwala w człowieku naturalny odruch obronny, a następnie uzasadniony sprzeciw i kontratak w celu eliminacji źródła niebezpieczeństwa. Uległość i bierność wobec zagrożenia powoduje jego nasilenie i całkowitą dominację. Wizja kataklizmów, wywołujących u człowieka atawistyczny lęk, w sposób szczególny pobudza ludzką wyobraźnię z uwagi na nieopisaną skalę potencjalnych zniszczeń i liczbę ofiar, jakie powoduje, a także świadomość nieuchronności tragedii i bezsilności wobec niej. Wkomponowanie tak fatalistycznych obrazów w kontekst społecznej aktywności środowisk LGBT kieruje uwagę ich przeciwników na potrzebę prowadzenia bardzo stanowczej dyskusji i bezkompromisowej narracji, przybierającej postać dyskursu wykluczenia.

\section{LITERATURE}

Kałuża M. „Choroba jako metafora w kontekście wykluczenia. Wariacje na temat metaforyzacji choroby w eseistyce Susan Sontag i Dżumie Alberta Camusa". Perspektywy Ponowoczesności. Tom 3: Wykluczenia. Kraków: Ośrodek Badawczy Facta Ficta, 2017: 231-242.

Kövecses Z. Metaphor: A practical introduction. Oxford: Oxford University Press, 2002.

Lakoff G., Johnson M. Metaphors We Live By. Chicago: University of Chicago Press, 1980.

Lakoff G. Nie myśl o stoniu! Jak język ksztattuje politykę. Warszawa: Oficyna Wydawnicza ŁOŚGRAF, 2011.

Maj E. „Język defaworyzacji w narodowodemokratycznej publicystyce prasowej (1918-1939)”. Polityka i Społeczeństwo (Rzeszów: Wydawnictwo Uniwersytetu Rzeszowskiego) 6 (2009): 64-72.

Naruszewicz-Duchlińska A. Nienawiść w czasach Internetu. Gdynia: Nova Res, 2015.

Niewiadomska I., Chwaszcz J. Jak skutecznie zapobiegać karierze przestępczej? Lublin: Drukarnia TEKST, 2010.

Partington A. „Metaphor, motifs and similes across discourse types: Corpus-assisted discourse studies (CAD)". Corpus-based approaches to metaphor and metonymy. Berlin: Mouton de Gruyter, 2006: 267-304.

Schwarz-Friesel M. Metaphern der Gewalt - Konzeptualisierung von Terrorismus in den Medien vor und nach 9/11. Tübingen: Narr Francke Attempto Verlag GmbH, 2014.

Sontag S. Choroba jako metafora. AIDS i jego metafory. Kraków: Wydawnictwo Karakter, 2016.

Witosz B. „O dyskursie wykluczenia i dyskursach wykluczonych z perspektywy lingwistycznej". Tekst $i$ dyskurs - Text und Diskurs (Warszawa: Wydawnictwo Uniwersytetu Warszawskiego) 3 (2010): 9-25.

Van Dijk T. A. „Critical discourse analysis”. The handbook of discourse analysis. Malden: Blackwell Publishers, 2001: 352-371.

Radosław Maziarz

THE METAPHOR OF DEFAVORIZATION IN THE DISCOURSE OF EXCLUSION. THE ANALYSIS OF INTERNET STATEMENTS OF LGBT OPPONENTS

Summary

The contemporary Polish public discourse related to the LGBT community is very firm and uncompromising. It is characterized by an explicit, dysphemistic, sometimes even aggres- 
sive language, which aims to depreciate and exclude this social group from public space. Above all, this is achieved through a metaphor of defavorization that is based on an anti-LGBT rhetoric, discrimination and segregation and can lead to social negation, hatred and ostracism. The language material under analysis is dominated by three main metaphors of defavorization, whose source domains are: terror/terrorism, disease and cataclysm. These concepts function in human consciousness as unquestionably negative and naturally evoke a number of pejorative connotations, such as fear, pain, mental and physical suffering, misfortune, destruction, killing, and death. These categories make the LGBT community conceptualized in public space in a very unfavorable way: it evokes aversion, lack of acceptance and even rejection. The metaphors activate mental models in the minds of the participants of the discourse, which perpetuate the negative social status of the LGBT community.

Key words: metaphor, discourse, defavorization, exclusion, LGBT.

\section{Радослав Мазијаж \\ МЕТАФОРИКА ДЕФАВОРИЗАЦИЈЕ У ДИСКУРСУ ИСКЉУЧИВАҢА. АНАЛИЗА ИНТЕРНЕТ АРГУМЕНТАЦИЈЕ ПРОТИВНИКА LGВТ}

\section{Резиме}

У овом чланку се разматра тема савременог пољског јавног дискурса усмереног на групације LGBT. Предмет истраживања представља изабрана интернет аргументација противника те социјалне групације. Анализа се темељи на значењима концептуалне метафоре са циљем да се издвоје метафоре дефаворизације или оне, које изражавају негативну оцену, депрецијацију, сегрегацију, дискриминацију ове групе и доводе до њене социјалне маргинализације. Анализа је показала да су доминантне три основне метафоре дефаворизације из сфере терора, болести и катаклизми. Ти појмови су праћени контекстом негативних конотација што показује да је социјална групација LGBT концептуализована у негативном контексту.

Кључне речи: метафора, дискурс, дефаворизација, маргинализација, LGBT. 